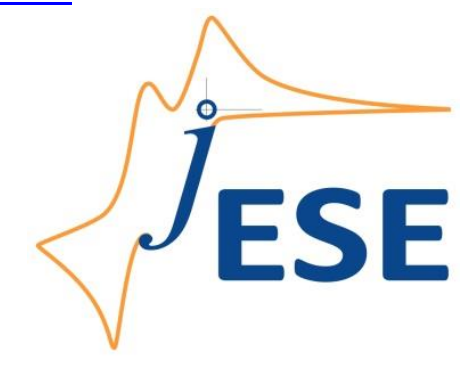

Open Access : : ISSN 1847-9286

www.jESE-online.org

Original scientific paper

\title{
A sensitive and simple method for voltammetric analysis of Sudan I as an azo dye in food samples using a $\mathrm{Fe}_{3} \mathrm{O}_{4}$-ZIF-67/ionic liquid modified carbon paste electrode
}

\author{
Mahboobeh Shahsavari and Iran Sheikhshoaie ${ }^{凶}$ \\ Department of Chemistry, Faculty of Science, Shahid Bahonar University of Kerman, Kerman \\ 76175-133, Iran
}

Corresponding author: $\rrbracket_{i}$ shoaie@yahoo.com

Received: December 24, 2021; Accepted: December 31, 2021; Published: January 19, 2022

\begin{abstract}
The present study developed a facile and fast electrochemical approach to sensitively analyze Sudan I using $\mathrm{Fe}_{3} \mathrm{O}_{4}$-ZIF-67 nanocomposite plus ionic liquid (IL). The carbon paste electrode (CPE) modified with $\mathrm{Fe}_{3} \mathrm{O}_{4}-\mathrm{ZIF}-67 / \mathrm{IL}$ exhibited an excellent electrochemical sensing performance to Sudan I. Compared with the unmodified CPE, $\mathrm{Fe}_{3} \mathrm{O}_{4}$-ZIF-67/ILCPE could significantly increase the peak current of Sudan I oxidation and decrease the oxidation overpotentials. Under the best experimental conditions, the sensor using differential pulse voltammetry (DPV) technique responded to Sudan I linearly $(0.5-560 \mu \mathrm{M})$ with a low limit of detection (LOD) of $0.1 \mu \mathrm{M}$. Additionally, the applicability and effectiveness of our proposed method in sensing Sudan I present in food samples was confirmed by acceptable recovery rate (96.0 - $103.6 \%)$.
\end{abstract}

\section{Keywords}

Electrochemical method; $\mathrm{Fe}_{3} \mathrm{O}_{4}$-ZIF-67 nanocomposite; ionic liquid;

\section{Introduction}

A group of Sudan azo dye (including types I, II, III and IV), known as important compounds, are synthetic industrial dyes that their carcinogenicity has been proven by IARC (International Agency for Research on Cancer) [1]. They are extensively applied as additives in chemistry preparations in the structure of fuels, oils, solvents, textile, coloring waxes, shoe polish, cosmetic products, and in the formulations of medical instruments and drugs owing to unique properties like high stability and cost-effectiveness [2]. Although most countries have issued restrictions on the use of these azo compounds as coloring additives, they are still present in the ingredients of some foods such as red peppers, sausages, relishes and condiments [3]. 1-phenylazo-2-naphthol, or Sudan I, were able to react with a certain DNA sequence under in vitro conditions. Therefore, this substance is toxic and damaging to genetic material [4]. Thus, a majority of countries enacted strict laws regarding the 
permissible use of Sudan I in food and beverages [5]. So, it is vital to detect the presence of Sudan I in various food products. Accordingly, many techniques have been employed so far for Sudan I detection, including high performing liquid chromatography [6], surface-enhanced Raman scattering method [7], fluorescence spectroscopy [8], enzyme-linked immunesorbent assay [9], capillary electrophoresis [10], and electrochemical methods [11].

Further attention has been recently attracted towards electrochemical methods owing to some unique properties such as rapid response, simple protocols, cost-effectiveness, real-time determination in situ condition and excellent sensitivity [12].

Consistent with recent evidence, Adams (1958) introduced carbon paste electrode (CPE) in electroanalysis [13] and to date, has been a facile tool for quantitative analysis of diverse compounds. CPEs have advantages such as easy preparation, low cost, the provision of repeatable signals [14], low background current, prolonged stability, wide polarization range in cathodic and anodic sides [15]. With these features in mind, special attention has been paid to the fabrication of inexpensive, facile and sensitive electrochemical sensors by CPEs for electroanalysis.

In this analytical method, electrode surface modification has been proposed using effective modifiers to enhance the efficiency of electrochemical measurements [16]. The electrode surface modification may play a role in enhancing the sensitivity of the electrochemical sensor with a low limit of detection (LOD). The chemical modification increases electron transfer, resulting in enhanced electrocatalytic properties at the electrode surface and reduced surface fouling [17]. Some effective modifiers include conductive polymers, nanomaterials, metal oxides, metals, composite materials and ionic liquids [18].

$\mathrm{Fe}_{3} \mathrm{O}_{4}$ nanoparticles are one of the most researched forms of iron oxides due to their attractive characteristics, including low toxicity, biocompatibility, super magnetism, and high surface area [19]. Moreover, this magnetic material is economical, easy to synthesize and more effective. These unique properties have enabled $\mathrm{Fe}_{3} \mathrm{O}_{4}$ nanoparticles to serve as an ideal candidate material in the electrochemical sensor [20-22].

Zeolitic imidazolate frameworks (ZIFs) belong to metal-organic frameworks (MOFs) and are appropriate porous materials containing inorganic metal nodes interconnected with ligands of imidazolate bridging or imidazole [23]. ZIFs possess common features of MOFs, and also have unique thermochemical stability [23]. Therefore, they are considered as proper options for gas adsorption [24], catalysis [25] and separation [26]. They also show very large surface area and excellent porosity, thus making them promising candidates for fabricating potent electrochemical sensors [27]. Hence, the incorporation of $\mathrm{ZIF}-67$ crystals and $\mathrm{Fe}_{3} \mathrm{O}_{4}$ nanoparticles can be useful to achieve potential applications.

lonic liquids (ILS) are salts in a liquid state at ambient temperatures and commonly consist of many organic cations and organic/inorganic anions. They have been extensively applied in electrochemistry because of excellent physicochemical properties like fairly great ionic conductivity, poor vapor pressure, admirable chemical stability, acceptable biocompatibility stable and electrochemical windows $[28,29]$.

The present research aimed to introduce a facile and sensitive electrochemical approach to detect Sudan I using $\mathrm{Fe}_{3} \mathrm{O}_{4}$-ZIF-67 nanocomposite and ionic liquid.

\section{Experimental}

\section{Chemicals and instrumentations}

Electrochemical experiments were recorded using a PGSTAT-302N Autolab potentiostat/galvanostat (Eco Chemie, The Netherlands). The control of all experiments was carried out by a General 
Purpose Electrochemical System (GPES) software. Electrochemical experiments were performed by a three-electrode system containing modified or unmodified $\mathrm{CPE}$ as working electrode, $\mathrm{Ag} / \mathrm{AgCl}$ $(3 \mathrm{M} \mathrm{KCl})$ as a reference electrode, and platinum wire as a counter (auxiliary) electrode. All pH values were measured by a digital Metrohm $710 \mathrm{pH}$ meter. All materials with analytical grade applied throughout this work were supplied from Aldrich and Merck.

The $\mathrm{Fe}_{3} \mathrm{O}_{4}$-ZIF-67 nanocomposite was synthesized according to a simple method as reported in our recent work [30]. The field emission scanning electron microscopy (FE-SEM) of $\mathrm{Fe}_{3} \mathrm{O}_{4}-\mathrm{ZIF}-67$ nanocomposite is shown in Figure 1.

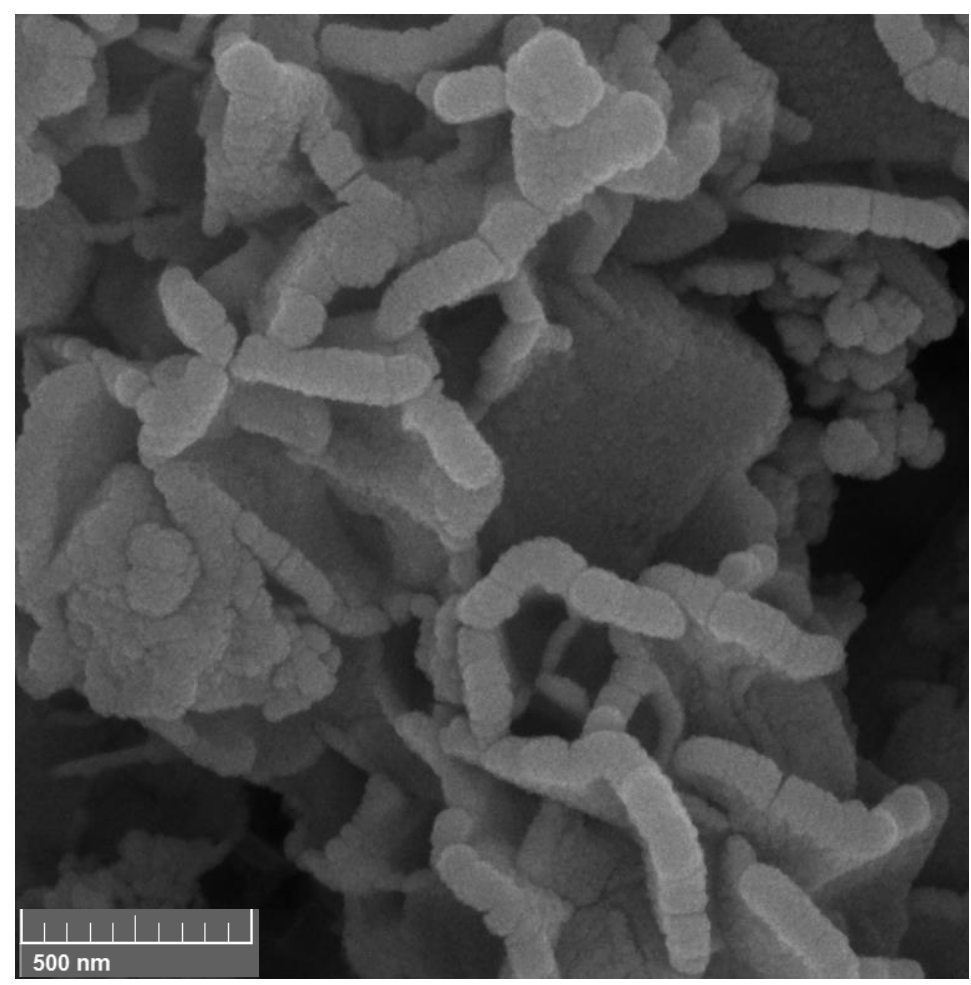

Figure 1. The FE-SEM image of $\mathrm{Fe}_{3} \mathrm{O}_{4}-\mathrm{ZIF}-67$ nanocomposite

\section{Preparation of $\mathrm{Fe}_{3} \mathrm{O}_{4}-\mathrm{ZIF-67/ILCPE}$}

For the preparation of $\mathrm{Fe}_{3} \mathrm{O}_{4}$-ZIF-67/ILCPE, $\mathrm{Fe}_{3} \mathrm{O}_{4}$-ZIF-67 nanocomposite was grounded with graphite powder with the ratio 10:90 (wt.\%), followed by mixing with paraffin oil and IL (1-butyl-3methylimidazolium hexafluorophosphate) (90:10 vol.\%) in a mortar and pestle for 30 min till a homogenous paste was obtained. The modified electrode was made by pressing the obtained modified paste into the bottom of a glass tube with the help of mechanical force. Then, electrical contact was made by placing a copper wire at the end of the syringe. If the electrode reaction tended to decrease, the electrode surface was polished on soft paper to give a smooth aspect before use.

The surface area of the $\mathrm{Fe}_{3} \mathrm{O}_{4}$-ZIF-67/ILCPE and the bare CPE were obtained by CV using $1 \mathrm{mM}$ $\mathrm{K}_{3} \mathrm{Fe}(\mathrm{CN})_{6}$ at different scan rates. Using the Randles-Sevcik formula for $\mathrm{Fe}_{3} \mathrm{O}_{4}$-ZIF-67/ILCPE, the electrode surface was found $0.288 \mathrm{~cm}^{2}$, about 3.2 times greater than bare CPE.

\section{Result and discussion}

The electrochemical response of Sudan I on the $\mathrm{Fe}_{3} \mathrm{O}_{4}$-ZIF-67/ILCPE surface

The supporting electrolyte $\mathrm{pH}$ significantly affects the Sudan I electrocatalysis on $\mathrm{Fe}_{3} \mathrm{O}_{4}$-ZIF-67/ILCPE surface. The $\mathrm{pH}$ influence on Sudan I detection in the presence of PBS on the modified electrode 
surface was explored at different $\mathrm{pH}$ values (2.0-9.0). The maximum peak current of Sudan I oxidation was found at the $\mathrm{pH}$ value of about 7.0; accordingly, this value was selected to be the optimal experimental condition for the experiments.

Figure 2 shows the application of the cyclic voltammetry (CV) method to evaluate the electrochemical behavior of $200.0 \mu \mathrm{M}$ Sudan I at different electrodes (unmodified CPE, and $\mathrm{Fe}_{3} \mathrm{O}_{4}-$ ZIF-67/ILCPE) in PBS (0.1 M, pH 7.0) at the scan rate of $50 \mathrm{mV} / \mathrm{s}$. Based on the results, there was an oxidation peak on the surfaces of electrodes, but no reduction peak, highlighting an irreversible electrochemical response of Sudan I on the electrodes. A relatively wide and weak peak current $\left(/_{\mathrm{pa}}\right)$ of Sudan I oxidation was found on the unmodified CPE (at $590 \mathrm{mV}$ with $5.5 \mu \mathrm{A}$ ), which reveals that the electrochemical oxidation does not happen spontaneously due to high activation overpotential. The Sudan I / pa on $\mathrm{Fe}_{3} \mathrm{O}_{4}$-ZIF-67/ILCPE, when compared with unmodified CPE, displayed further elevation to $13.1 \mu \mathrm{A}$, meaning an increase up to 2.4 times that on the unmodified CPE. In addition, Sudan I oxidation occurred at a lower potential than unmodified CPE.

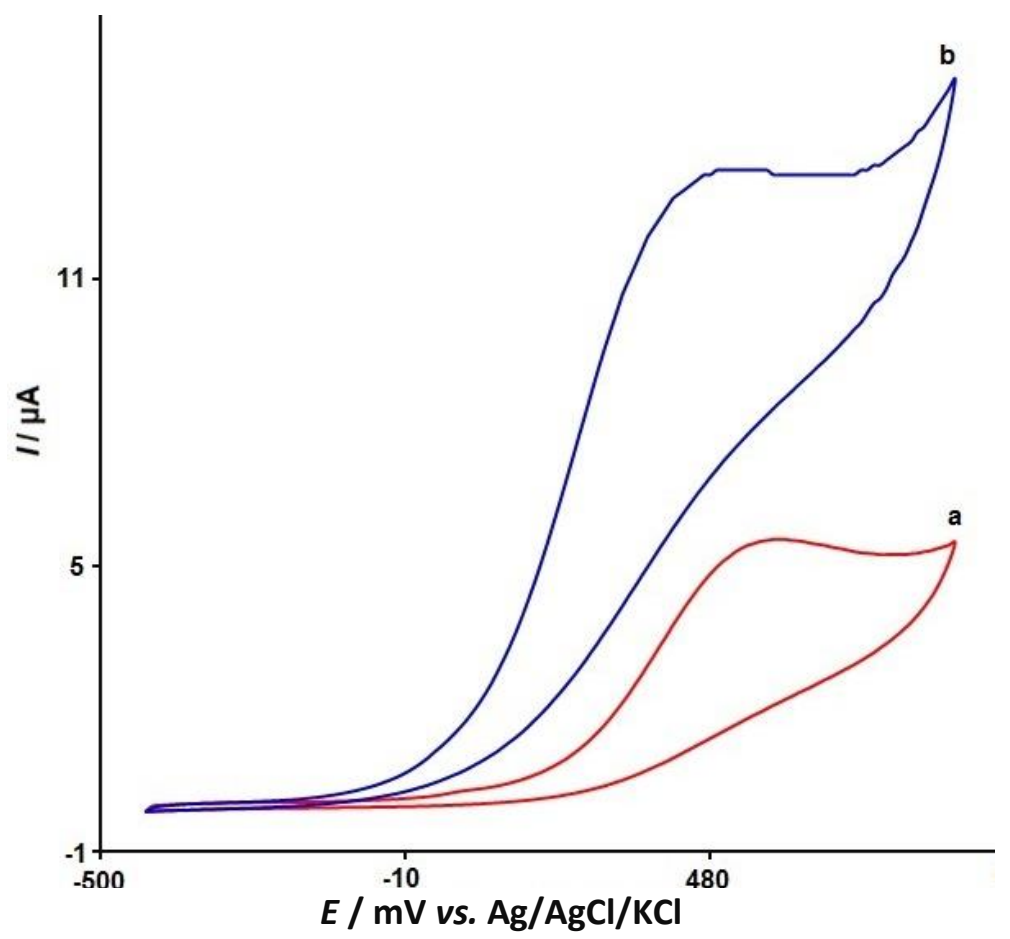

Figure 2. CV response of $200.0 \mu \mathrm{M}$ Sudan I at (a) unmodified CPE, (b) $\mathrm{Fe}_{3} \mathrm{O}_{4}-\mathrm{ZIF-67/ILCPE}$ in PBS (0.1 M, pH 7.0)

Effect of scan rate on the results

Figure 3 displayed the linear sweep voltammetry (LSV) behaviors of $100.0 \mu \mathrm{M}$ Sudan I in PBS at the $\mathrm{pH}$ value of 7.0 at variable scan rates on the surface of $\mathrm{Fe}_{3} \mathrm{O}_{4}$-ZIF-67/ILCPE. Based on the results, there was a gradual elevation in the peak current of Sudan I oxidation and a positive shift of peak potential of oxidation by rising the scan rates to $10 \mathrm{from} 400 \mathrm{mV} / \mathrm{s}$. According to Figure 3 (inset), the Sudan I anodic peak current $\left(I_{\mathrm{pa}}\right)$ fitted to the square root of scan rate $\left(v^{1 / 2}\right)$. Hence this study showed that the electrode reaction was a diffusion-controlled process.

To provide data about the rate determining step, a Tafel plot was drawn based on data of rising sector related to the current-voltage curve at low scan rate $(10 \mathrm{mV} / \mathrm{s})$ for $100.0 \mu \mathrm{M}$ Sudan I (Figure 4, inset). The linearity of $E$ versus log I plot reveals the intervention of electrode process kinetics. In accordance with the slope of this plot, the number of transferred electrons can be calculated in the rate-determining step. The inset in Figure 4 shows the Tafel slope of $0.2312 \mathrm{~V}$ for the linear sector. The Tafel slope value means the rate-limiting step related to one-electron transfer, with a transfer coefficient $\alpha$ of 0.74 . 


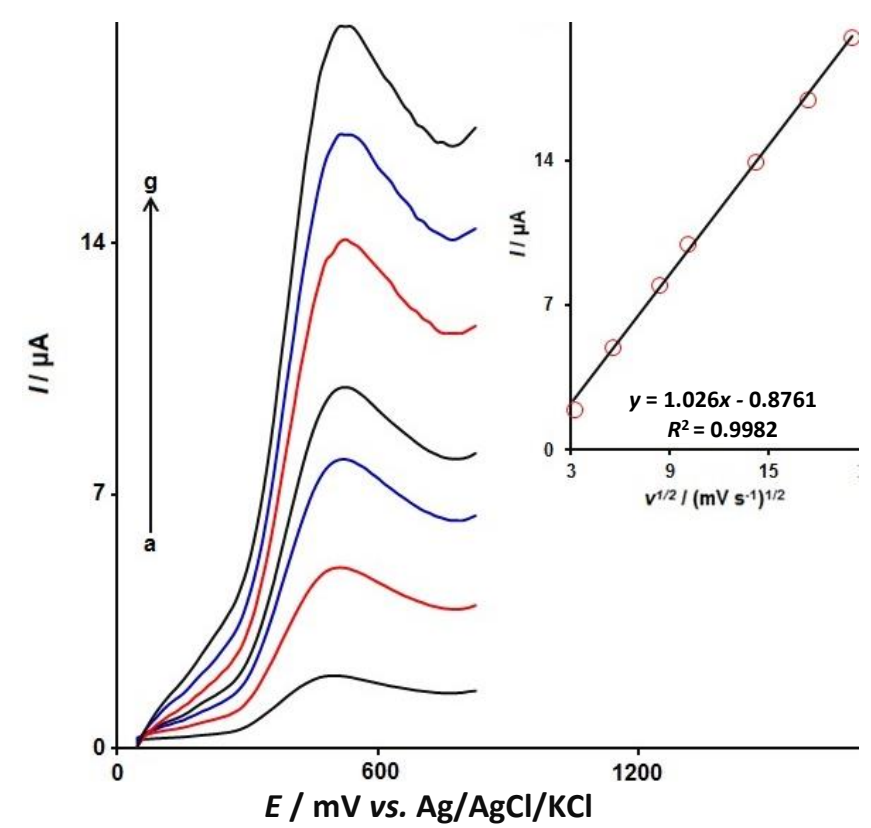

Figure 3. $L S V$ curves of $100.0 \mu \mathrm{M}$ Sudan I in PBS $(0.1 \mathrm{M}, \mathrm{pH} 7.0)$ at different scan rates $(10-400 \mathrm{mV} / \mathrm{s})$ on $\mathrm{Fe}_{3} \mathrm{O}_{4}-\mathrm{ZIF}-67 / \mathrm{ILCPE}$ (a-g refers to 10,30, 70, 100, 200.0, 300.0, and $\left.400.0 \mathrm{mV} / \mathrm{s}\right)$. Inset: Plot of scan rate square root versus Sudan I oxidation peak current

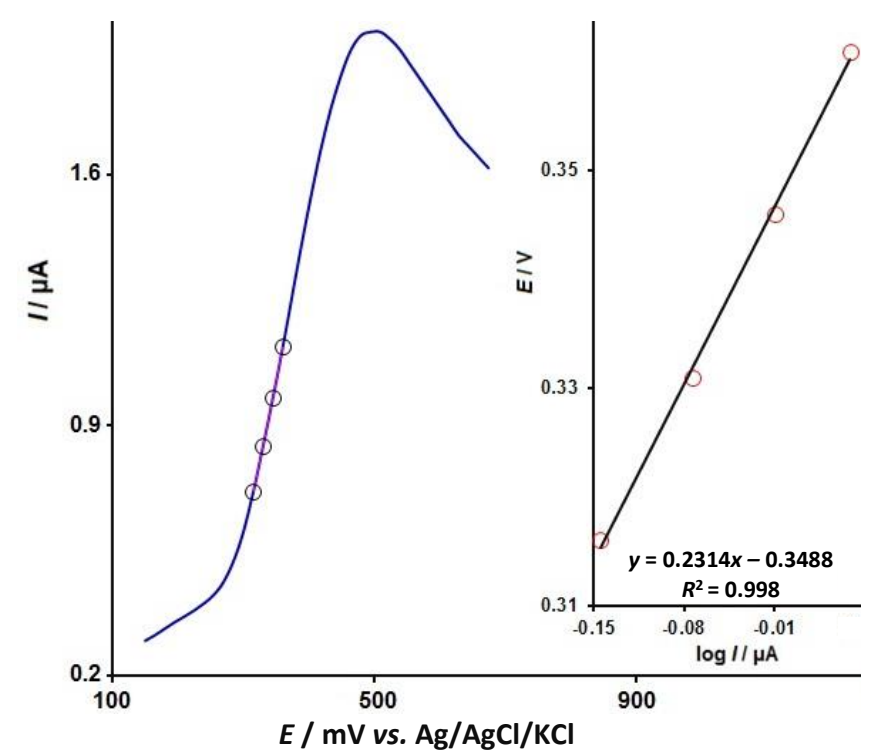

Figure 4. LSV response for $100.0 \mu \mathrm{M}$ of Sudan I at the scan rate of $10 \mathrm{mV} / \mathrm{s}$; inset: Tafel plot of rising sector or related voltammogram

\section{Chronoamperometric analysis}

Chronoamperometric records for Sudan I detection on the $\mathrm{Fe}_{3} \mathrm{O}_{4}$-ZIF-67/ILCPE surface were performed using a working electrode with the potential of $0.58 \mathrm{~V}$ at variable Sudan I in PBS (0.1 M, $\mathrm{pH}$ 7.0), as shown in Figure 5. The Cottrell equation describes the electrochemical reaction current at the limited condition of mass transport for Sudan I (as an electroactive material) with a certain $D$ value [31]. Figure 5A shows the experimental plots of $I$ versus $t^{-1 / 2}$ with the optimal fits at variable Sudan I concentrations. Then, we plotted the slopes of obtained straight lines versus Sudan I concentration, as shown in Figure 5B. Based on the achieved slope and Cottrell equation, the mean $D$ value was estimated at $1.5 \times 10^{-6} \mathrm{~cm}^{2} / \mathrm{s}$. 


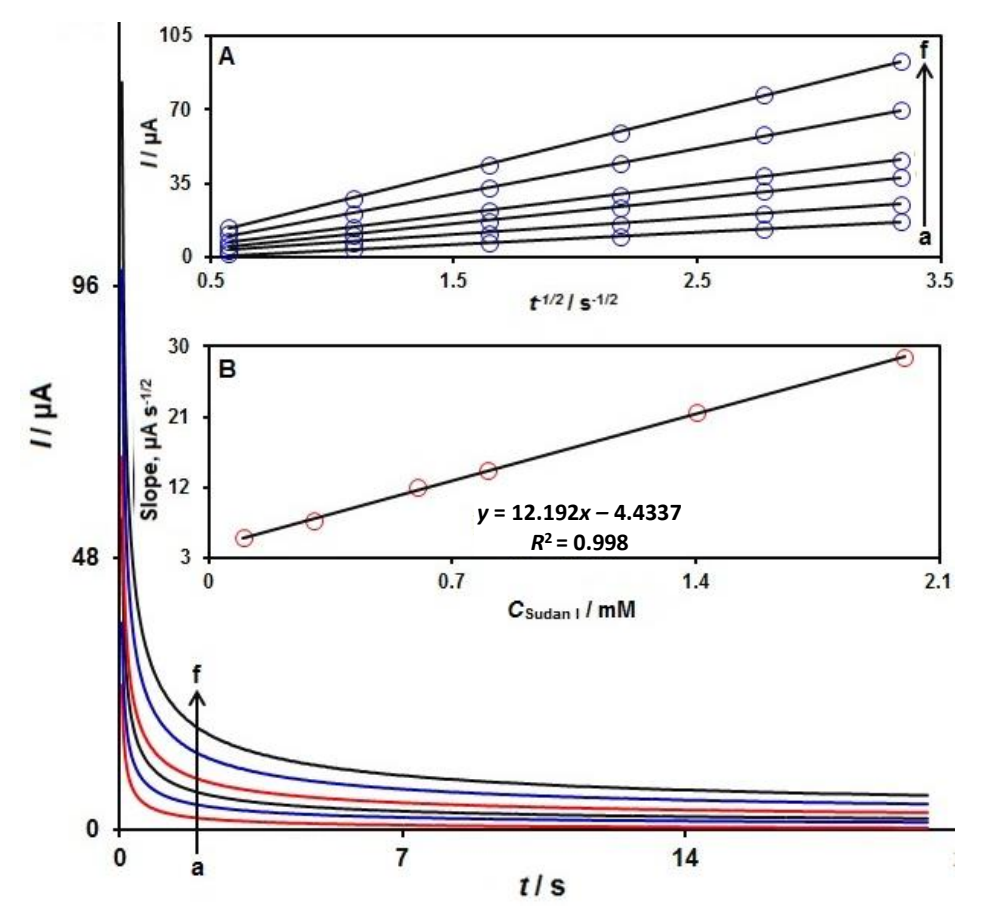

Figure 5. The chronoamperograms obtained on $\mathrm{Fe}_{3} \mathrm{O}_{4}$-ZIF-67/ILCPE in PBS $(0.1 \mathrm{M}, \mathrm{pH} 7.0)$ at different Sudan I concentrations; Note) $a-f: 0.1,0.3,0.6,0.8,1.4$, and $2.0 \mathrm{mM}$ of Sudan I. Inset $A$ ) plot of I versus $\mathrm{t}^{-1 / 2}$ based on chronoamperograms $(a-f)$. Inset $B$ ) slope plot of straight line versus Sudan I concentration

\section{DPV analysis of Sudan I on the $\mathrm{Fe}_{3} \mathrm{O}_{4}$-ZIF-67/ILCPE surface}

DPV is a versatile technique for Sudan I detection because of its higher sensitivity and the obtained voltammograms for Sudan I detection is shown in Figure 6 (Step potential $=0.01 \mathrm{~V}$ and pulse amplitude $=0.025 \mathrm{~V}$ ).

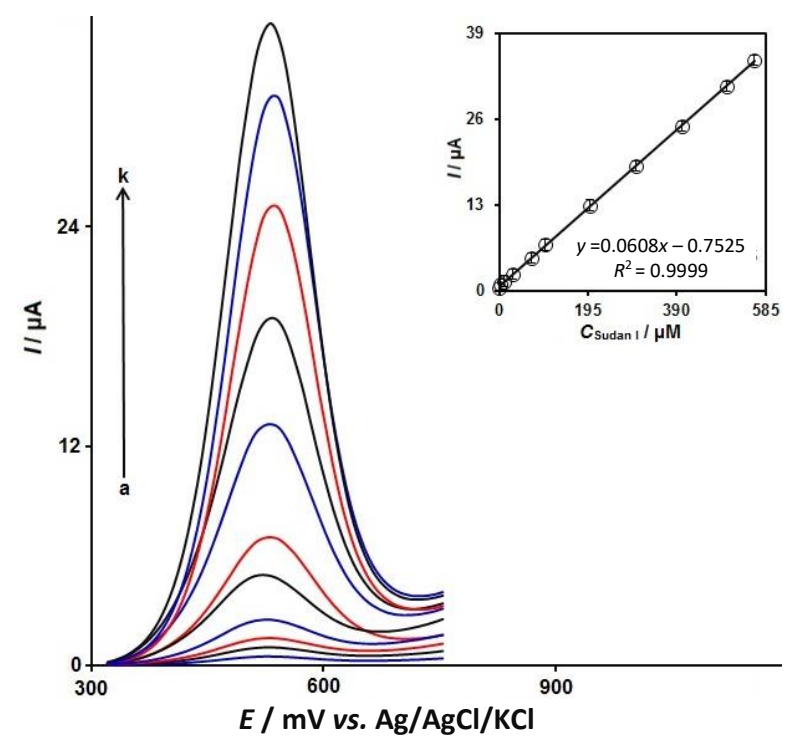

Figure 6. DPV response of Sudan I at $\mathrm{Fe}_{3} \mathrm{O}_{4}-\mathrm{ZIF-67/ILCPE}$ in the concentration range $0.5-560.0 \mu \mathrm{M}$ in PBS (0.1 M, pH 7.0); a-k refers to 0.5, 2.5, 10.0, 30.0, 70.0, 100.0, 200.0, 300.0, 400.0, 500.0, and 560.0 $\mu \mathrm{M}$; inset: The calibration curve of DPV peaks against concentration of Sudan I

Figure 6 shows that with increasing concentration of Sudan I from 0.5 to $560.0 \mu \mathrm{M}$ the $I_{\mathrm{pa}}$ is elevated with a slight shift in oxidation potential. The $I_{\text {pa }}$ plot versus Sudan I concentration was drawn (Figure 6 , inset), the results of which display a nearly straight line with admirable linearity having linear regression equation of $I_{\mathrm{pa}}=0.0608 C_{\text {sudan } 1}+0.7525\left(R^{2}=0.9999\right)$. The equation of $3 \mathrm{Sb} / \mathrm{m}$ was considered to compute the LOD, where $\mathrm{m}$ stands for the slope of the standard plot and $S_{\mathrm{bl}}$ for a 
standard deviation for linearity of blank solution anodic peak current after five determinations. The LOD is found to be $0.1 \mu \mathrm{M}$. Table 1 presents a comparison of $\mathrm{Fe}_{3} \mathrm{O}_{4}$-ZIF-67/ILCPE analytical performance created in this work with other electrochemical sensors involved in Sudan I analysis.

Table 2. Comparison of the determination of Sudan I at $\mathrm{Fe}_{3} \mathrm{O}_{4}-\mathrm{ZIF-67/ILCPE}$ and modified electrodes reported in the literature

\begin{tabular}{|c|c|c|c|c|}
\hline Electrochemical sensor & Method & Linear range, $\mu \mathrm{M}$ & Limit of detection, $\mu \mathrm{M}$ & Ref. \\
\hline $\begin{array}{c}\text { Ag nanoparticles decorated graphene } \\
\text { oxide/glassy carbon electrode }\end{array}$ & Amperometry & $3.90 \times 10^{-3}-3.19 \times 10^{-2}$ & $11.4 \times 10^{-4}$ & {$[32]$} \\
\hline $\begin{array}{c}\text { CuO nanoparticles-decorated 3D N-doped } \\
\text { porous carbon/glassy carbon electrode }\end{array}$ & DPV & $2.0 \times 10^{-3}-0.1$ & $8.4 \times 10^{-4}$ & {$[33]$} \\
\hline $\begin{array}{c}\text { Gemini surfactant-ionic liquid-multiwalled } \\
\text { carbon nanotube/glassy carbon electrode }\end{array}$ & $\begin{array}{c}\text { Linear sweep } \\
\text { voltammerey }\end{array}$ & $5.0 \times 10^{-5}-2.0 \times 10^{-3}$ & $3.0 \times 10^{-5}$ & {$[34]$} \\
\hline $\mathrm{Bi}_{2} \mathrm{WO}_{6}$ nanosheets/glassy carbon electrode & DPV & $0.02-114.6$ & 0.002 & {$[35]$} \\
\hline Fe $\mathrm{O}_{4}$-ZIF-67/ILCPE & DPV & $0.5-560.0$ & 0.1 & This work \\
\hline
\end{tabular}

\section{Real sample analysis}

The applicability of the sensor developed in the present study was tested by detecting Sudan I present in real food specimens, including chili powder and ketchup sauce. Table 2 shows the recovery rates of 96.0 to $103.6 \%$ for spiked specimens. These results indicated the effectiveness of the proposed sensor in the detection of Sudan I in real specimens.

Table 2. Sudan I detection in real food specimens using $\mathrm{Fe}_{3} \mathrm{O}_{4}-\mathrm{ZIF-67/ILCPE} \mathrm{(n=5)}$

\begin{tabular}{|c|c|c|c|c|}
\hline \multirow{2}{*}{ Sample } & \multicolumn{2}{|c|}{$C / \mu \mathrm{M}$} & \multirow{2}{*}{ Recovery, \% } & \multirow{2}{*}{ RSD, $\%$} \\
\hline & Spiked & Found & & \\
\hline \multirow{5}{*}{ Chili powder } & 0 & ND & - & - \\
\hline & 5.0 & 4.9 & 98.0 & 3.2 \\
\hline & 7.0 & 7.1 & 101.4 & 1.7 \\
\hline & 9.0 & 8.8 & 97.8 & 2.9 \\
\hline & 11.0 & 11.4 & 103.6 & 2.3 \\
\hline \multirow{5}{*}{ Ketchup sauce } & 0 & ND & - & - \\
\hline & 5.0 & 5.1 & 102.0 & 1.8 \\
\hline & 7.5 & 7.4 & 98.7 & 3.5 \\
\hline & 10.0 & 9.6 & 96.0 & 2.2 \\
\hline & 12.5 & 12.6 & 100.8 & 2.6 \\
\hline
\end{tabular}

\section{Conclusion}

In this work, the $\mathrm{Fe}_{3} \mathrm{O}_{4}$-ZIF-67 nanocomposite was synthesized via a simple method and characterized by various microscopic and spectroscopic methods. This $\mathrm{Fe}_{3} \mathrm{O}_{4}$-ZIF-67/ILCPE was applied to determine Sudan I. According to our results, an admirable potential was reported for the $\mathrm{Fe}_{3} \mathrm{O}_{4}$-ZIF-67 nanocomposite and IL for Sudan I detection, with a narrow limit of detection (0.1 $\left.\mu \mathrm{M}\right)$ and broad linear dynamic range $(0.5-560.0 \mu \mathrm{M})$. The developed sensor demonstrated satisfactory applicability for Sudan I detection in real food specimens.

\section{References}

[1] X. Nie, Y. Xie, Q. Wang, H. Wei, C. Xie, Y. Li, B. Wang, Y. Li, CyTA-Journal of Food 19 (2021) 560-570. https://doi.org/10.1080/19476337.2021.1925746

[2] H. Chen, M. Chen, X. Wang, R. Sun, Polymer Chemistry 5 (2014) 4251-4258. https://doi.org/ 10.1039/C4PY00120F

[3] Q. Zhou, M. Lei, Y. Wu, S. Li, Y. Tong, Z. Li, M. Liu, L. Guo, C. Chen, Chemosphere 279 (2021) 130584. https://doi.org/10.1016/i.chemosphere.2021.130584 
[4] H. Mahmoudi-Moghaddam, S. Tajik, H. Beitollahi, Food Chemistry 286 (2019) 191-196. https://doi.org/10.1016/i.foodchem.2019.01.143

[5] X. Ma, M. Chao, Z. Wang, Food Chemistry 138 (2013) 739-744. https://doi.org/10.1016/ j.foodchem.2012.11.004

[6] E. Ertaş, H. Özer, C. Alasalvar, Food Chemistry 105 (2007) 756-760. https://doi.org/10.1016/ j.foodchem.2007.01.010

[7] M.I. López, I. Ruisánchez, M.P. Callao, Spectrochimica Acta Part A: Molecular and Biomolecular Spectroscopy 111 (2013) 237-241. https://doi.org/10.1016/i.saa.2013.04.031

[8] S. Anmei, Z. Qingmei, C. Yuye, W. Yilin, Analytica Chimica Acta 1023 (2018) 115-120. https://doi.org/10.1016/i.aca.2018.03.024

[9] D. Han, M. Yu, D. Knopp, R. Niessner, M. Wu, A. Deng, Journal of Agricultural and Food Chemistry 55 (2007) 6424-6430. https://doi.org/10.1021/if071005j

[10] E. Mejia, Y. Ding, M.F. Mora, C.D. Garcia, Food Chemistry 102 (2007) 1027-1033. https://doi.org/10.1016/i.foodchem.2006.06.038

[11] X. Li, X. Sun, M. Li, ChemistrySelect 5 (2020) 12777-12784. https://doi.org/10.1002/slct. $\underline{202003559}$

[12] M. Heydari, S.M. Ghoreishi, A. Khoobi, Measurement 142 (2019) 105-112. https://doi.org/ 10.1016/i.measurement.2019.04.058

[13] R. N. Adams, Analytical Chemistry 30 (1958) 1576-1579.

[14] B. J. Sanghavi, A. K. Srivastava, Electrochimica Acta 55 (2010) 8638-8648. https://doi.org/ 10.1016/j.electacta.2010.07.093

[15] I. G. Svegl, B. Ogorevc, Journal of Analytical Chemistry 367 (2000) 701-706. https://doi.org/ $10.1007 / \mathrm{s} 002160000465$

[16] G. Jeevanandham, K. Vediappan, Z. A. Alothman, T. Altalhi, A. K. Sundramoorthy, Scientific Reports 11 (2021) 1-13. https://doi.org/10.1038/s41598-021-92620-2

[17] M. R. Ganjali, F. Garkani-Nejad, S. Tajik, H. Beitollahi, E. Pourbasheer, B. Larijanii, International Journal of Electrochemical Science 12 (2017) 9972-9982. https://doi.org $\angle 10.20964 / 2017.11 .49$

[18] Y. Yao, X. Han, X. Yang, J. Zhao, C. Chai, Chinese Journal of Chemistry 39 (2021) 330-336. https://doi.org/10.1002/cjoc.202000398

[19] J. K. Patra, K. H. Baek, Journal of Photochemistry and Photobiology B: Biology 173 (2017) 291-300. https://doi.org/10.1016/i.jphotobiol.2017.05.045

[20] Y. Xie, T. Zhang, Y. Chen, Y. Wang, L. Wang, Talanta 2020, 213 (2020) 120843. https://doi.org/10.1016/i.talanta.2020.120843

[21] B. Sriram, M. Govindasamy, S. F. Wang, R. J. Ramalingam, H. Al-Lohedan, T. Maiyalagan, Ultrasonics Sonochemistry 58 (2019) 104618. https://doi.org/10.1016/j.ultsonch.2019. 104618

[22] H. Li, B. Kou, Y. Yuan, Y. Chai, R. Yuan, Biosensors and Bioelectronics 197 (2022) 113758. https://doi.org/10.1016/i.bios.2021.113758

[23] K.S. Park, Z. Ni, A.P. Côté, Proceedings of the National Academy of Sciences 103 (2006) 10186-10191. https://doi.org/10.1073/pnas.0602439103

[24] S.R. Venna, M.A. Carreon, Journal of the American Chemical Society 132 (2009) 76-78. https://doi.org/10.1021/ja909263x

[25] C. Chizallet, S. Lazare, D. Bazer-Bachi, F. Bonnier, V. Lecocq, E. Soyer, A. A. Quoineaud, N. Bats, Journal of the American Chemical Society 132 (2010) 12365-12377. https://doi.org/ $\underline{10.1021 / j a 907359 t}$

[26] H. Bux, F. Liang, Y. Li, J. Cravillon, M. Wiebcke, J. Caro, Journal of the American Chemical Society 131 (2009) 16000-16001. https://doi.org/10.1021/ja907359t 
[27] S. L. Li, Q. Xu, Energy \& Environmental Science 6 (2013) 1656-1683. https://doi.org/10.1039/ C3EE40507A

[28] M. C. Buzzeo, R. G. Evans, R. G. Compton, ChemPhysChem 5 (2004) 1106-1120. https://doi.org/10.1002/cphc.200301017

[29] A. Abo-Hamad, M. A. Alsaadi, M. Hayyan, I. Juneidi, M. A. Hashim, Electrochimica Acta 193 (2016) 321. https://doi.org/10.1016/i.electacta.2016.02.044

[30] M. Shahsavari, S. Tajik, I. Sheikhshoaie, H. Beitollahi, Topics in Catalysis (2021). https://doi.org/10.1007/s11244-021-01471-8

[31] A. J. Bard, L. R. Faulkner Fundamentals and applications. Electrochemical methods (2001) pp 580-632.

[32] E. Prabakaran, K. Pandian, Food Chemistry 166 (2015) 198-205. https://doi.org/10.1016/j. foodchem.2014.05.143

[33] Q. Ye, X. Chen, J. Yang, D. Wu, J. Ma, Y. Kong, Food Chemistry 287 (2019) 375-381. https://doi.org/10.1016/i.foodchem.2019.02.108

[34] Z. Mo, Y. Zhang, F. Zhao, F. Xiao, G. Guo, B. Zeng, Food Chemistry 121 (2010) 233-237. https://doi.org/10.1016/i.foodchem.2009.11.077

[35] V. Vinothkumar, A. Sangili, S. M. Chen, T. W. Chen, M. Abinaya, V. Sethupathi, International Journal of Electrochemical Science 15 (2020) 2414-2429. https://doi.org/10.20964/2020.03.08 
